\title{
Influence of information and communication technology in secondary school administration in Abia State
}

\author{
Nkemjika Chika ${ }^{1,}{ }^{*}$ and Raji Wale I ${ }^{2}$ \\ ${ }^{1}$ Department of Educational Management. Education Faculty of Education, Rivers State University, Nigeria. \\ ${ }^{2}$ Department of Vocational and Technology Education Faculty of Education, Rivers State University, Nigeria.
}

Publication history: Received on 07 April 2020; revised on 16 April 2020; accepted on 17 April 2020

Article DOI: https://doi.org/10.30574/gscarr.2020.3.1.0025

\begin{abstract}
The study investigated the influence of information and communication technology in secondary school administration in Abia state. The objectives of the study was to determine the influence of Information and communication Technology on students' administration, personnel administration, financial administration, and supervision of instructions in secondary schools in Abia State. The study adopted a descriptive survey research design. The population of the study comprised all secondary school teachers and school administrators in Abia State. Stratified random sampling was used to select 138 teachers and 39 administrators based on the three senatorial districts in Abia state (Abia-Central, AbiaNorth and Abia-South). The instrument used for data collection was survey questionnaire which was self-constructed in four point rating scale by the researcher. The instrument was validated by two research experts. The reliability coefficient of the instrument was estimated using Cronbach Alpha. The coefficient of the instrument obtained was 0.81 which indicated the reliability strength of the instrument. Mean and standard deviation were the statistical tools used to analyze the data gathered from the respondents on each of the research questions. Z-test was used to test the null hypothesis at 0.05 level of significance. Findings of the study showed that application of information and communication technology is capable of improving the delivery of administration service in secondary schools. The study recommended that government should provide adequate computers and ICT tools in schools especially for administrative purposes and teaching and learning.
\end{abstract}

Keywords: Influence; Information; Communication; Technology; Administration; Schools

\section{Introduction}

The modern society has continue to experience consistent change in the ways of doing things over the years. This is because modern society is characterized by rise in information and communication technology usage in all spheres of the society. The rapid growth in information and communication technology had brought notable changes in the twenty first century and has affected the demands of the modern societies. ICT is becoming increasingly important in our day to day lives even the education system is not excluded. Information and communication technology is a new wave of technology that necessitates innovation and development in various sectors of the society. It comprises diverse range of technologies that enables easier access to information, storage, retrieval, communication among others.

[1] and [2] saw information and communication technology as an embodiment of two operating systems which are information technology and communication technology. They further described information technology as one that deals with the collection, storage, manipulation and transfer of information using electronic means while communication technology refers to the physical devices and software that link various computers hardware components and transfer data from one physical location to another. In this view ICT entails all technologies that are

\footnotetext{
* Corresponding author: Nkemjika Chika
} 
capable of collecting, storing, retrieving, transferring, and sharing information from one device to the other or from one point to the other. ICT refers to a wide range of computerized technologies that enables communication and the electronic capturing, processing, and transmission of information. These technologies include products and service such as desktop computers, laptops, hand-held devices, wired or wireless connectivity, business productivity software, data storage \& security, network security, other related protocols, etc. [3]. ICT (information and communication technology) in its widest sense is technological tools and resources used to communicate, create, organize, disseminate, store, retrieve, and manage information [4],[5], [6], [7].

Over the years, various kinds of ICT devices or tools have emerged to enhance the speed and quality of service delivery and radically change services being handled in all sectors of the society worldwide. Considering the education sector, [8] notably expressed that right from the early days efforts are continuously being made to increase interest, attention and investment by the students, educators and investors to put them all into the use of the ICT in education in the schools.

The inculcation of information and communication technology in the administrative system of the school is considered to be part of the extensive technological modernization of administration and education, as well as of the Information Society's action for electronic government (e-Government) and electronic learning (eLearning) [9]. E-government is a system of organizing and directing the activities certain group of persons in order to accomplish a specified end using ICT devices. School administration is a tasking responsibility that involve the coordination of both human and material resources to accomplish a pre-defined objectives. However, the emergence of ICT in the modern society has necessitated the implementation of advanced technologies for the performance of various administrative works within the school organization [10].

Due to the fact school administration involves the unification of human and material resources to achieve academic goals. Basically, there are crucial aspect of school administration that requires full integration information and communication technology for better performance of school administrators as stated in the model developed by [11] and [12]. They categorized ICT based information administration in schools into five aspects which are student administration, personnel administration, financial administration, instruction supervision and general administration.

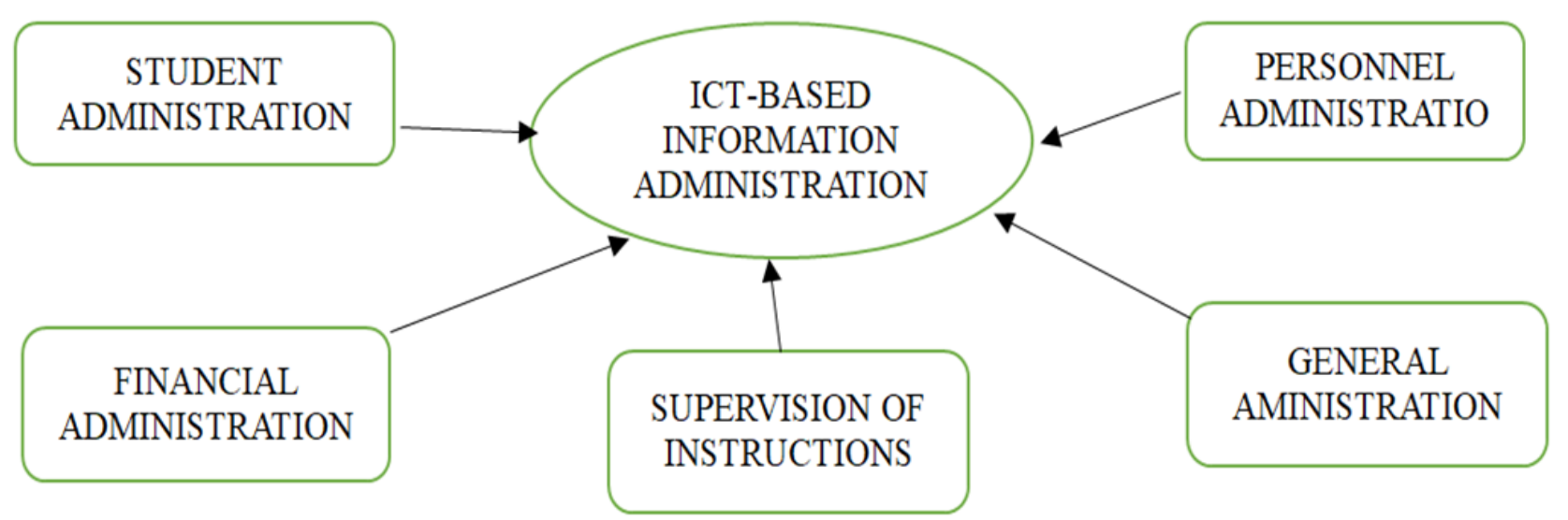

Figure 1 Makewa, Meremo, Role and Role (2013) and Maki (2008)

ICT integration plays a vital role in supporting powerful and efficient management in the education sector [12]. Owing to memory capacities of computers, large chunks of data can be stored in them. They enable quick processing of data with very less or no chances of errors in processing. Networked computers aid quick communication and enable web access. Storing documents on computers in the form of soft copies instead of hard ones, helps save paper and quick administrative service [13]. Edefiogho [6] made it clear that ICT increases the efficiency and effectiveness of educational management and administration. According to him, if managerial functions at school and other levels of the education system are to be carried out efficiently and effectively, it is necessary that information of high quality is available at all times for elective decision-making. ICT has enforced numerous changes in administration services, it is in this view that [14] opined that there have been increasing changes for administrators in the areas of leadership expectation, work demands, schools and personal accountability, human resources management, decision-making communication, power and authority, and planning. These changes demand that the school administrator must be computer literate to cope with the demands on him/her. 
In the study of Gurr in [15] discovered that principals make use of spreadsheets, e-mail and word processing, and they also identified various software management systems increasingly used to do budgeting and planning. Such database systems are usually loaded on the jurisdiction server so that personnel can retrieve information about school statistics or access accounting, budgeting and reporting systems at any time. Utilizing ICT in school administration, principals can store lasting information on staff/students' personal data, browse the internet for up-to-date information, make returns/writing mails, register students online for WASCE/NECO examinations, deliver interesting papers in workshop/seminars using power point display, communicate with colleagues in other parts of the world, and retrieve information for prompt action in decision-making, among others [16].

Again, [9] noted that within school administration ICT is implemented for the development of electronic applications for the management of administrative transactions and records, as well as for the rendering of well-organized and prompt information services (i.e. electronic register, electronic curriculum, digital lesson material, electronic monitoring of school progress). [17] stated that ICT:

- assists school administration in the efficient management of official functions, in the enhanced supervision of student progress, as well as in the improvement of school resources management,

- contributes to an easier and friendlier management of complicated and multilevel administrative transactions, and

- promotes communication between school units, parents, and principal administration, and therefore cultivates responsibility on the part of school management, transparency in administrative actions, as well as the interlinking of school networks.

[9] expressly pointed that ICT provides the means for administrative transactions to be accomplished with electronic management tools, in a digital environment, which is composed of decentralized, yet interlinked, web-based services.

[18] has outlined a framework that suggests eight categories of ICT leadership that include: equitable providing, learning-focused envisioning, adventurous learning, protective enabling, constant monitoring, networking and challenging. It is to this end that [19] further supported that leader who is close to the curriculum and teaching are well placed to influence pedagogical change through ICT. Similarly, [20] supports the notion that school leadership harness commitment to improve teaching and learning through ICT integration. From the foregoing, it is obvious and worthy to conclude that ICT is an efficient system that can enhance communication and social relationship between principals, teacher, students and supervisors. Instructional supervision is one of the processes by which school administrators attempt to achieve acceptable standards of performance and results. Instructional supervisory activities such as lesson plan supervision, curriculum implementation, classroom management, teachers' punctuality and attendance among others in the modern society is enhanced using various ICT tools such as e-mails, closed circuit television, skype, and other social media platforms

Management of school finances is another major aspect of school administration that requires the implementation of ICT tools to enhance of administrative efficiency. ICT creates an enabling atmosphere that integrates all financial transactions with the help of accounting software to generate financial reports needed to influence the decision of potential and existing investors [3]. Generally ICT is considered one of the most reliable means of providing a strong platform for effective system of internal control over financial reporting. It stands to reason that a sound ICT system provides a sure and guarantee medium of financial information delivery that covers the entire accounting cycle of the school.

Many at times principals are saddled with magnanimous responsibilities that requires immediate attention at a time. There are concomitant management demands being exerted on the principal, especially in this Information and Communication Technology (ICT) era. The enormous rise in the number of students in schools a s well as the numerous programmes coupled with the complexity of administering a given secondary school has made school principals to handle large volumes of data which they must process quickly [21].

\section{Purpose of the study}

The major purpose of the study was to determine the influence of information and communication technology in secondary school Administration in Abia State. In specific terms the study sought to 
- Determine the influence of Information and communication Technology on students administration in secondary schools in Abia state

- Determine the influence of Information and communication Technology on personnel administration in secondary schools in Abia state

- Determine the influence of Information and communication Technology on financial administration in secondary schools in Abia state

- Determine the influence of Information and communication Technology on supervision of instructions in secondary schools in Abia state.

\section{Research Questions}

\subsection{The following questions guided the study}

- What are the influence of Information and communication Technology on students' administration in secondary schools in Abia state?

- What are the influence of Information and communication Technology on personnel administration in secondary schools in Abia state?

- What are the influence of Information and communication Technology on financial administration in secondary schools in Abia state?

- What are the influence of Information and communication Technology on supervision of instructions in secondary schools in Abia state?

\section{Hypotheses}

- There is no significant difference in the mean responses of teachers and school administrators on the influence of Information and communication Technology on school administration (students, personnel, financial and supervision of instruction) in secondary schools in Abia State.

\section{Methodology}

Based on the fact that the study required gathering responses from both teachers and school administrators in Abia State, the study adopted a descriptive survey research design. The population of the study comprised all secondary school teachers and school administrators in Abia State. Stratified random sampling was used to select 138 teachers and 39 administrators based on the three senatorial districts in Abia state (Abia-Central, Abia-North and Abia-South). The instrument used for data collection was survey questionnaire which was self-constructed in four point rating scale by the researcher. The instrument consisted of two sections, section one elicited responses on the personal data of the respondents and section two consisted the item questions that carefully addressed each of the research questions. The validity of the instrument was affirmed by two research experts in the department of educational management, Rivers State University. The reliability coefficient of the instrument was estimated using Cronbach Alpha. The coefficient of the instrument obtained was 0.81 which indicated the reliability strength of the instrument. Mean and standard deviation were the statistical tools used to analyze the data gathered from the respondents on each of the research questions. Due to the fact that four point rating scale instrument was used in data collection, criterion mean value of 2.50 was set for decision of acceptance and rejection. That is, items with mean responses of $\geq 2.50$ were accepted while items $<2.50$ were rejected. Z-test was used to test the null hypothesis at 0.05 level of significance.

\section{Results}

\subsection{Research Question 1}

What are the influence of Information and communication Technology on students' administration in secondary schools in Abia State? 
Table 1 Mean responses of teachers and administrators on the influence of Information and communication Technology on students' administration in secondary schools in Abia State

\begin{tabular}{|c|c|c|c|c|c|c|c|}
\hline \multirow[b]{2}{*}{ S/N } & \multirow[b]{2}{*}{ Items } & \multicolumn{3}{|c|}{ Teachers= 138} & \multicolumn{3}{|c|}{ School Administrators=39 } \\
\hline & & Mean & S.D & Remark & Mean & S.D & Remark \\
\hline & ICT helps to enhance & & & & & & \\
\hline 1 & $\begin{array}{l}\text { Tracking of students' } \\
\text { enrolment record }\end{array}$ & 3.20 & 0.87 & Agreed & 3.56 & 0.73 & Agreed \\
\hline 2 & $\begin{array}{l}\text { Measurement } \\
\text { performance metrics and } \\
\text { grading }\end{array}$ & 3.00 & 0.80 & Agreed & 3.32 & 0.68 & Agreed \\
\hline 3 & $\begin{array}{l}\text { Students' examination } \\
\text { conduct }\end{array}$ & 3.65 & 0.92 & Agreed & 3.51 & $0 . .81$ & Agreed \\
\hline 4 & Time table scheduling & 3.40 & 0.79 & Agreed & 3.42 & 0.92 & Agreed \\
\hline 5 & $\begin{array}{l}\text { Reporting of students } \\
\text { performance }\end{array}$ & 3.66 & 0.67 & Agreed & 3.74 & 0.83 & Agreed \\
\hline 6 & $\begin{array}{ll}\text { Communication } & \text { from } \\
\text { teachers to students } & \end{array}$ & 3.51 & 0.92 & Agreed & 3.60 & 0.53 & Agreed \\
\hline 7 & $\begin{array}{l}\text { Effective handling } \\
\text { students' of } \\
\text { appeal }\end{array}$ & 3.47 & 0.87 & Agreed & 3.86 & 0.64 & Agreed \\
\hline 8 & $\begin{array}{l}\text { Management of students } \\
\text { personal records }\end{array}$ & 3.09 & 0.90 & Agreed & 3.34 & 0.83 & Agreed \\
\hline 9 & $\begin{array}{l}\text { Maintenance of school } \\
\text { policies and procedure }\end{array}$ & 3.23 & 0.73 & Agreed & 3.08 & 0.87 & Agreed \\
\hline & Grand Mean \& S.D & 3.36 & 0.83 & & 3.46 & 0.75 & \\
\hline
\end{tabular}

Table 1 presents the mean responses of teachers and administrators on the influence of information and communication technology on students' administration in secondary schools in Abia State. The table revealed with the mean responses beyond the criterion mean value of 2.50 that ICT helps to enhance tracking of students' enrolment record ( $3.20 \& 3.56)$, measurement of performance metrics and grading (3.00 \& 3.32), students' examination conduct (3.65 \& 3.51), time table scheduling ( $3.40 \& 3.42$ ), reporting of students performance (3.66 \& 3.74), Communication from teachers to students (3.51 \& 3.60), effective handling of students' complaints and appeal (3.47 \& 3.86), management of students personal records ( $3.09 \& 3.34$ ), and maintenance of school policies and procedure (3.23 \& 3.08).

\subsection{Research Question 2}

What are the influence of Information and communication Technology on personnel administration in secondary schools in Abia state?

Table 2 presents the mean responses of teachers and school administrators on the influence of Information and communication Technology on personnels' administration in secondary schools in Abia State. Based on the criterion mean value of 2.50, the table revealed that information and communication technology helps to enhance personnel recruitment (3.32 \& 3.40), employee examining and selection (3.78 \& 3.67), personnel professional development (3.10 \& 3.52), evaluation of effective classroom teaching ( $3.48 \& 3.65)$, staff motivation ( $3.56 \& 3.72$ ), staff payment ( 3.87 \& $3.46)$, social relation among teachers and parents (3.32 \& 3.76), employee appraisal (3.63 \& 3.68) and Job function of the teacher ( $3.56 \& 3.42)$. 
Table 2 Mean responses of teachers and administrators on the influence of Information and communication Technology on personnels' administration in secondary schools in Abia State

\begin{tabular}{|c|c|c|c|c|c|c|c|}
\hline \multirow[b]{2}{*}{$\mathbf{S} / \mathbf{N}$} & \multirow[b]{2}{*}{ Items } & \multicolumn{3}{|c|}{ Teachers $=138$} & \multicolumn{3}{|c|}{ School Administrators $=39$} \\
\hline & & Mean & S.D & Remark & Mean & S.D & Remark \\
\hline & ICT helps to enhance & & & & & & \\
\hline 1 & Personnel recruitment & 3.32 & 0.87 & Agreed & 3.40 & 0.98 & Agreed \\
\hline 2 & $\begin{array}{l}\text { Employee examining and } \\
\text { selection }\end{array}$ & 3.78 & 0.69 & Agreed & 3.67 & 0.87 & Agreed \\
\hline 3 & $\begin{array}{l}\text { Personnel } \\
\text { development }\end{array}$ & 3.10 & 0.91 & Agreed & 3.52 & 0.76 & Agreed \\
\hline 4 & $\begin{array}{l}\text { Evaluation of effective classroom } \\
\text { teaching }\end{array}$ & 3.48 & 0.83 & Agreed & 3.65 & 0.90 & Agreed \\
\hline 5 & Staff motivation & 3.56 & 0.80 & Agreed & 3.72 & 0.79 & Agreed \\
\hline 6 & Staff payment & 3.87 & 0.67 & Agreed & 3.46 & 0.93 & Agreed \\
\hline 7 & $\begin{array}{l}\text { Social relation among teachers } \\
\text { and parents }\end{array}$ & 3.32 & 0.90 & Agreed & 3.76 & 0.98 & Agreed \\
\hline 8 & Employee appraisal & 3.63 & 0.87 & Agreed & 3.68 & 0.90 & Agreed \\
\hline \multirow[t]{2}{*}{9} & Job function of the teacher & 3.56 & 0.90 & Agreed & 3.42 & 0.87 & Agreed \\
\hline & Grand Mean \& S.D & 3.51 & 0.83 & & 3.59 & 0.89 & \\
\hline
\end{tabular}

\subsection{Research Question 3}

What are the influence of Information and communication Technology on financial administration in secondary schools in Abia state?

Table 3 Mean responses of teachers and administrators on the influence of Information and communication Technology on financial administration in secondary schools in Abia State

\begin{tabular}{llllllll}
\hline & & \multicolumn{3}{c}{ Teachers=138 } & \multicolumn{3}{c}{ School Administrators=39 } \\
S/N & Items & Mean & S.D & Remark & Mean & S.D & Remark \\
\hline \multirow{2}{*}{$\begin{array}{l}\text { ICT helps to facilitate } \\
1\end{array}$} & Proper account records & 3.56 & 0.87 & Agreed & 3.78 & 0.78 & Agreed \\
2 & Preparation of school budget & 3.76 & 0.80 & Agreed & 3.65 & 0.91 & Agreed \\
3 & school financial reports & 3.80 & 0.62 & Agreed & 3.69 & 0.94 & Agreed \\
4 & Preparation self-checklist & 3.59 & 0.98 & Agreed & 3.34 & 0.76 & Agreed \\
& $\begin{array}{l}\text { Documentation and calculation } \\
\text { of operational funding }\end{array}$ & 3.68 & 0.73 & Agreed & 3.32 & 0.81 & Agreed \\
6 & $\begin{array}{l}\text { payment of teachers and other } \\
\text { operational funding }\end{array}$ & 3.62 & 0.91 & Agreed & 3.86 & 0.65 & Agreed \\
& Grand Mean and S.D & 3.67 & 0.82 & & 3.61 & 0.81 & \\
\hline
\end{tabular}

Table 3 presents the mean responses of teachers and administrators on the influence of Information and communication Technology on financial administration in secondary schools in Abia State. The table shows that all the items had mean higher than the criterion mean, hence all the items were accepted. That is, ICT helps to facilitate proper account records (3.56 \& 3.78), preparation of school budget ( $3.76 \& 3.65$ ), school financial reports (3.80 \& 3.69), preparation selfchecklist ( $3.59 \& 3.34$ ), documentation and calculation of operational funding (3.68 \& 3.32) and payment of teachers and other operational funding ( $3.62 \& 3.86)$. 


\subsection{Research Question 4}

What are the influence of Information and communication Technology on supervision of instructions in secondary schools in Abia state?

Table 4 Mean responses of teachers and administrators on the influence of Information and communication Technology on supervision of instructions in secondary schools in Abia State

\begin{tabular}{|c|c|c|c|c|c|c|c|}
\hline \multirow[b]{2}{*}{ S/N } & \multirow[b]{2}{*}{ Items } & \multicolumn{3}{|c|}{ Teachers $=138$} & \multicolumn{3}{|c|}{ School Administrators = 39} \\
\hline & & Mean & S.D & Remark & Mean & S.D & Remark \\
\hline & ICT helps in & & & & & & \\
\hline 1 & Observation of teachers performance & 3.65 & 0.87 & Agreed & 3.68 & 0.87 & Agreed \\
\hline 2 & $\begin{array}{l}\text { Management of human and material } \\
\text { resources }\end{array}$ & 3.76 & 0.65 & Agreed & 3.76 & 0.76 & Agreed \\
\hline 3 & $\begin{array}{l}\text { Maximization of available resources for } \\
\text { teaching }\end{array}$ & 3.50 & 0.70 & Agreed & 3.28 & 0.98 & Agreed \\
\hline 4 & $\begin{array}{l}\text { Monitoring teachers compliance to } \\
\text { school policies }\end{array}$ & 3.40 & 0.87 & Agreed & 3.08 & 0.92 & Agreed \\
\hline 5 & $\begin{array}{l}\text { Bringing teachers to minimum standard } \\
\text { for effective teaching }\end{array}$ & 3.67 & 0.92 & Agreed & 3.36 & 0.68 & Agreed \\
\hline 6 & $\begin{array}{l}\text { Improving teachers competence for } \\
\text { modern teaching }\end{array}$ & 3.86 & 1.00 & Agreed & 3.52 & 0.87 & Agreed \\
\hline \multirow[t]{2}{*}{7} & $\begin{array}{l}\text { Enhance working with groups of teachers } \\
\text { to adapt local curriculum and to } \\
\text { improving teaching method }\end{array}$ & 3.87 & 0.87 & Agreed & 3.64 & 0.69 & Agreed \\
\hline & Grand Mean \& S.D & 3.67 & 0.87 & & 3.47 & 0.82 & \\
\hline
\end{tabular}

Table 4 presents the mean responses of teachers and administrators on the influence of Information and communication Technology on supervision of instructions in secondary schools in Abia State. The table showed that ICT helps in observation of teachers' performance (3.65 \& 3.68), management of human and material resources (3.76 \& 3.76), maximization of available resources (3.50 \& 3.28), monitoring teachers compliance to school policies (3.40 \& 3.08), bringing teachers to minimum standard for effective teaching (3.67 \& 3.36), improving teachers competence for modern teaching (3.86 \& 3.52), enhance working with groups of teachers to adapt local curriculum and to improve teaching method (3.87 \& 3.64).

\section{Hypothesis}

There is no significant difference in the mean responses of teachers and school administrators on the influence of Information and communication Technology on school administration (students, personnel, financial and supervision of instruction) in secondary schools in Abia State.

Table 5 reveals Z-test analysis on the influence of Information and communication Technology on school administration (students, personnel, financial and supervision of instruction) in secondary schools in Abia State. The table shows that the $z$-values obtained from the computation $(0.65,0.52,0.41,1.28)$ were less than the $z$-crit value of 1.96 . Hence, it was concluded that the opinion of teachers and school administrators on the influence of Information and communication Technology on school administration are not significantly different each other. 
Table 5 Z-test analysis on the influence of Information and communication Technology on school administration (students, personnel, financial and supervision of instruction) in secondary schools in Abia State.

\begin{tabular}{|c|c|c|c|c|c|c|c|c|}
\hline $\begin{array}{l}\text { Influence of ICT } \\
\text { in }\end{array}$ & $\begin{array}{l}\text { Category } \\
\text { respondents }\end{array}$ & $\mathbf{N}$ & Mean & S.D & $\mathbf{Z}$ & z-crt & Remark & \\
\hline \multirow{2}{*}{$\begin{array}{l}\text { Students } \\
\text { administration }\end{array}$} & Teachers & 138 & 3.36 & 0.86 & \multirow[t]{2}{*}{0.65} & \multirow[t]{2}{*}{1.96} & \multirow{2}{*}{$\begin{array}{l}\text { Fail } \\
\text { reject }\end{array}$} & to \\
\hline & Administrators & 39 & 3.46 & 0.75 & & & & \\
\hline \multirow{2}{*}{$\begin{array}{l}\text { Personnel } \\
\text { Administration }\end{array}$} & Teachers & 138 & 3.51 & 0.83 & \multirow[t]{2}{*}{0.52} & \multirow[t]{2}{*}{1.96} & \multirow{2}{*}{\multicolumn{2}{|c|}{$\begin{array}{l}\text { Fail } \\
\text { reject }\end{array}$}} \\
\hline & Administrators & 39 & 3.59 & 0.89 & & & & \\
\hline \multirow{2}{*}{$\begin{array}{l}\text { Financial } \\
\text { Administration }\end{array}$} & Teachers & 138 & 3.67 & 0.82 & \multirow[t]{2}{*}{0.41} & \multirow[t]{2}{*}{1.96} & \multirow{2}{*}{\multicolumn{2}{|c|}{$\begin{array}{l}\text { Fail to } \\
\text { reject }\end{array}$}} \\
\hline & Administrators & 39 & 3.61 & 0.81 & & & & \\
\hline \multirow{2}{*}{$\begin{array}{l}\text { Supervision } \\
\text { instruction }\end{array}$} & Teachers & 138 & 3.67 & 0.87 & \multirow[t]{2}{*}{1.28} & \multirow[t]{2}{*}{1.96} & \multirow{2}{*}{\multicolumn{2}{|c|}{$\begin{array}{l}\text { Fail } \\
\text { reject }\end{array}$}} \\
\hline & Administrators & 39 & 3.47 & 0.82 & & & & \\
\hline
\end{tabular}

\section{Discussion}

Findings of the study revealed that ICT helps to enhance tracking of students' enrolment record, measurement of performance metrics and grading, students' examination conduct, time table scheduling, reporting of students performance, communication from teachers to students, effective handling of students' complaints and appeal, management of students personal records, maintenance of school policies and procedure. The finding is in line with [16] who noted that in school administration, principals can store lasting information on staff/students' personal data, browse the internet for up-to-date information, make returns/writing mails, register students online for WASCE/NECO examinations, deliver interesting papers in workshop/seminars using power point display, communicate with colleagues in other parts of the world, and retrieve information for prompt action in decision-making, among others.

The study also showed that information and communication technology helps to enhance personnel recruitment, employee examining and selection, personnel professional development, evaluation of effective classroom teaching, staff motivation, staff payment, social relation among teachers and parents, employee appraisal, Job function of the teacher. This is in conformity with [11] who stated that personnel administration is one of the significant areas of school administration that requires full implementation of ICT. More specifically, [17] noted that ICT promotes communication between school units that is, students, employees and the principals which therefore cultivates responsibility on the part of school management, transparency in administrative actions, as well as the interlinking of school networks. [14] Opined that there have been increasing changes for administrators in the areas of leadership expectation, work demands, schools and personal accountability, human resources management, decision-making communication, power and authority, and planning.

Moreover, the study found that ICT helps to facilitate proper account records, preparation of school budget, school financial reports, preparation self-checklist, documentation and calculation of operational funding and payment of teachers and other operational funding. This findings is similar to the findings of [3] who asserted that ICT creates an enabling atmosphere that integrates all financial transactions with the help of accounting software to generate financial reports needed to influence the decision of potential and existing investors. Also [9] expressly pointed that ICT provides the means for administrative transactions to be accomplished with electronic management tools, in a digital environment, which is composed of decentralized, yet interlinked, web-based services.

Finally, the study found that ICT helps in observation of teachers' performance, management of human and material resources, maximization of available resources, monitoring teachers' compliance to school policies, bringing teachers to minimum standard for effective teaching, improving teachers' competence for modern teaching, enhance working with groups of teachers to adapt local curriculum and to improving teaching method. This is in conformity with [22] and [20] who observed that majority of instructional supervisory activities can now be performed online using ICT tools. 
They further supported that the integration of ICT in instructional supervision has helped teachers harness commitment to improve teaching and learning.

\section{Conclusion}

Based on the finding of the study the study concluded that the application of information and communication technology is capable of improving the delivery of administration service in secondary schools. In this information age, every spheres of the society is greatly influenced by the rising trend of technologies that enables dissemination of information in no seconds. In response to this, this study found that various administration activities in schools can be greatly enhanced and carried out at a higher level of accuracy with the use of emerging information and communication technologies designed for this purpose.

\section{Recommendations}

The findings of the study necessitate that

- Government should provide adequate computers and ICT tools in schools especially for administrative purposes and teaching and learning.

- School administrators should be trained on how to utilize available social media networks and other ICT tools for interconnectivity among parents, teachers and students.

- Government should mandate all secondary schools to effectively utilize emerging technologies for school and administrative activities, this will enable the students and other academic personnel accustom themselves with current technology trends and fit for global demands.

- ICT initiation requires certain technical and financial competences in terms of suitable infrastructures and building requirements, ongoing and in-house technical assistance and the ability to upgrade and update the existing equipment, software and electronic applications.

\section{Compliance with ethical standards}

\section{Acknowledgments}

We are deeply indebted to Abia state secondary school administrators (Principals and the vice principals) and teachers whose sincere responses made this study possible. We are very grateful for your kind responses to questionnaires distributed in the course of this study.

\section{Disclosure of conflict of interest}

Both authors declare that they have no conflict of interest for publishing this article.

\section{References}

[1] Laudon KC and Laudon JP. (2010). Management Information System, New Jersey: Pearson Education Inc.

[2] Adeyemi TO and Olaleye FO. (2010) Information and communication technology (ICT)for the effective management of secondary schools for sustainable development in Ekiti State, Nigeria. AmericanEurasian; Journal of Scientific Research, 5(2), 106-113.

[3] Andrabi SM, Kirmani M and Wani F. (2017). Impact of ICT on Effective Financial Management. International Journal of Information Science and System, 4, 1-14.

[4] Obi C. (2002). Information technology skills needed by business education teachers for effective instruction in the secondary schools in Enugu State. The Journal of World Council for Curriculum and Instruction, Nigeria Chapter, 4(2), 99-106.

[5] Yusuf MO. (2005). Information and Communication Technology and Education: Analysing the Nigerian National Policy for Information Technology. International Education Journal, 6(3), 316-321.

[6] Edefiogho DH. (2005). Information and communication technology and overall development: New frontiers Shekinah home coming. Nsukka: Stanzero Printers. 
[7] Chaka JG. (2008). Information and communication technology (ICT) as a vital tool in the education sector reform in Nigeria. Nigerian Journal of Sociology in Education (NJSE), 2(2), 181-190.

[8] Afzaal HS. (2012). A preliminary study of school administrators' use of information and communication technologies: Bruneian perspective. International Journal of Education and Development using Information and Communication Technology (IJEDICT), 8(1), 29-45.

[9] Saiti A and Prokopiadou G. (2009). Impact of Information and Communication Technologies on School Administration: Research on the Greek Schools of Secondary Education. Electronic Government, (5693), 305316.

[10] Adebayo A. (2011). Principles and practice of public administration. Ibadan: Spectrum Books Ltd.

[11] Makewa L, Meremo J, Role E and Role J. (2013). ICT in secondary school administration in rural southern Kenya: An educator's eye on its importance and use. International Journal of Education and Development using Information and Communication Technology (IJEDICT), 9(2), 48-63.

[12] Maki C. (2008). "Information and communication technology for administration and management of secondary schools" Journal of online learning and teaching, 4(3), 18-20.

[13] Ogwo E Maidoh NE and Onwe CE. (2015). Computer Studies and Its impact in Secondary Schools in UmuahiaNorth Local Government Area of Abia State, Nigeria. International Journal of Modern Education and Computer Science, 5(6), 16-23.

[14] Oboegbulem AI and Ogbonnaya NO. (2008). Challenges in the application of information and communication technology (ICT) in the management of universities. In B. G. Nworgu (Ed.), Education in the information age: Global challenges and enhancement strategies. Proceedings of the First International Conference of the Faculty of Education, University of Nigeria, Nsukka.

[15] Haugley M. (2002). Impact of ICT on the work of the school principal. Involving the academic: A test for University ITEM systems, 63-71.

[16] Oboegbulem AI and Ugwu RN. (2008). The Place of ICT (Information and Communication Technology) in the Administration of Secondary Schools in South Eastern States of Nigeria. US-China Education Review, (3)4, 231238.

[17] Haddad W and Jurich S. (2002). ICT for education: potential and potency. In: Haddad, W., Drexler, A. (eds.) Technologies for education: potentials, parameters, and prospects. Academy for Educational Development and Paris, Washington.

[18] Yee DL. (2000). "IT in Educational Leadership: New Zealand Perspective".

[19] Kearney G and McGarr O. (2009). "The Role of the Teaching Principal in Promoting ICT Use in Small Primary Schools in Ireland". Technology, Pedagogy and Education, 18(1), 87-102.

[20] Hayes DNA. (2007). “ICT and Learning: Lessons from Australian Classroom”. Computers \& Education, 49(2), 385395.

[21] Asiabaka IP. (2010). Access and use of information and communication technology (ICT) for administrative purposes by principals of government secondary schools in Nigeria. The Researcher, 2(1), 43-50.

[22] Sule MA, Ameh E and Egbai ME. (2015). Instructional Supervisory Practices and Teachers' Role Effectiveness in Public Secondary Schools in Calabar South Local Government Area of Cross River State, Nigeria. Journal of Education and Practice, 6(23), 43-47.

\section{How to cite this article}

Nkemjika C and Raji WI. (2020). Influence of information and communication technology in secondary school administration in Abia State. GSC Advanced Research and Reviews, 3(1), 26-35. 